\title{
The Mediating Role Mobile Technology Plays in the Linkage between Customer Satisfaction and Customer Loyalty
}

\author{
Chihombori Rumbidzai Anna \\ University of Fort Hare Department of Business Management \\ P Bag X1314 Alice 5700 South Africa, \\ rueacy@gmail.com \\ Jordaan B.D \\ University of Fort Hare Department of Business Management \\ P Bag X1314 Alice 5700 South Africa, \\ bdjordaan@ufh.ac.za \\ Matikiti Rosemary \\ University of Fort Hare Department of Business Management, \\ P Bag x1314, Alice, 5700, South Africa, \\ matikiti@gmail.com
}

\section{Doi:10.5901/mjss.2014.v5n20p639}

\begin{abstract}
Since the turn of the century there have been major advancements in mobile technology and this has resulted in change of strategies to build customer satisfaction and customer loyalty by clothing retailers. These advancements have created a need to be competitive in this arena for clothing retailers. In this modern era which is highly customer-centred concepts such as attracting customer satisfaction and customer loyalty are of importance to clothing retailers. Research literature shows that there is limited work which focused on the mediating role of mobile technology on customer satisfaction and customer loyalty. Hence this paper seeks to identify the mediating role of mobile technology in the linkage between customer satisfaction and customer loyalty. The main objective of this paper was to critically investigate the mediating role that the use of mobile technology plays in the linkage between customer satisfaction and customer loyalty in a semi-urban environment. A questionnaire containing mainly structured questions was used as a data collection instrument. The outcome from regression analysis shows that mobile phones have become a basic necessity for customers and that mobile technology plays a mediating role in the linkage between customer satisfaction and customer loyalty; though the mediation is partial.
\end{abstract}

Keywords: Mobile Technology, Customer Satisfaction, Customer Loyalty and Mobile Technology

\section{Introduction}

Since the start of the new millennium, marketing research and marketing practice has rekindled the importance of understanding the role of customer satisfaction in several ways. The pressure on businesses today is increased by a market where the customer acquisition rate is slowing, customer loyalty is decreasing and sales cycles are lengthening (Roberts-Lombard, 2009:070). Customer satisfaction is an important predictor not only of customer loyalty, but also of the profitability of a firm's marketing activities (Evanschitzky \& Wunderlich, 2006: 331; Zeithaml, Rust, \& Lemon, 2001:119). According to Roberts-Lombard (2009:073), the ultimate aim of any business is to ensure that the customer that buys its product or service is satisfied.

Various developments in South Africa such as political changes, high inflation rates and the implementation of the New Credit Control Act in 2007, have severely negatively affected customer's lifestyles and expenditure levels. Performing trade worldwide is inevitability rather opulence in most industries (Abbasi, Khalid, Azam \& Riaz, 2010:97). Practically all tactical decisions today are embroidered by global concerns (Abbasi, et al., 2010:97). Competition is also ferocious in retailing. Therefore, firms need to understand consumer behaviours. The clothing industry is characterised by short product life cycles, tremendous product variety, volatile and unpredictable demand and inflexible supply processes (Fashion Apparel Industry Overview, 2011).The industry is also being affected by transition through increasing use of 
electronic commerce in retail (Fashion Apparel Industry Overview, 2011). The use of electronic commerce helps marketers to build relationships with customers. The advent of the use of technology has motivated firms to apply mobile technology to communicate with customers in order to build loyalty. Limited research studies explored the mediating role mobile technology plays in the linkage between customer satisfaction and customer loyalty in South Africa and specifically on the performance of clothing retailers. Hence this paper seeks to close this gap.

\subsection{Statement of the problem}

In these times of intensifying competition, eroding customer loyalty, economic uncertainty and changing customer expectations, firms have adopted a proactive approach in formulating loyalty strategies. Most South African customers are empowered with high levels of knowledge about their rights. In addition, the emergence of more educated consumers has called for more customer-driven firms resulting in increased customer satisfaction and the building of customer loyalty. The retail segment of the market faces one of the greatest challenges when it comes to competition (Badler, 2004:143). The factor of competition compels firms to build customer loyalty.

Limited research studies explored the mediating role mobile technology plays in the linkage between customer satisfaction and customer loyalty in South Africa and specifically on the performance of clothing retailers. The concept of service quality is of importance to firms since it influences customer satisfaction and customer loyalty. The concept of service quality and its influence on customer loyalty is also of importance. Since the turn of the century there have been major advancements in mobile technology and hence, clothing retailers need to be competitive in this arena. A gap exists between customer expectations of products or services and the performance of these products or services; hence, there is disconfirmation in expectations and performance that causes this gap. The research problem that is derived from this gap is:

The application of mobile technology in the linkage between customer satisfaction and customer loyalty in the clothing industry in King Williams Town remains unclear and unexplored.

With this backdrop, clothing retailers focus on customer satisfaction and loyalty in order to build long-term relationships with their customers and to meet customer expectations. Therefore, the main aim of the research is to critically investigate the mediating role that the application of mobile technology by retailing clothing stores plays in the linkage between customer satisfaction and customer loyalty in a semi-urban environment. The research will specifically investigate the use of mobile communication to achieve customer satisfaction and loyalty.

\subsection{Research purpose}

The main purpose of this paper was to critically investigate the mediating role that the use of mobile technology plays in the linkage between customer satisfaction and customer loyalty in a semi-urban environment. The research problem focused on the application of mobile technology in the linkage between customer satisfaction and customer loyalty in the clothing industry in King Williams Town.

\subsection{Objectives}

The objective of this article is to investigate the influence of the independent variable Customer satisfaction on customer loyalty via the intervening variable mobile technology. From this main objective the following hypotheses were formulated;

\subsection{Hypotheses}

The relationship between the independent variable and the dependent variable

- $\mathrm{H1}_{1}$ :Customer Satisfaction does not have an influence on customer loyalty of customers of clothing retailers.

- $\mathrm{H} 1_{1}$ :Customer Satisfaction does have an influence on customer loyalty of customers of clothing retailers.

The relationship between the intervening variable and the dependent variable

- H2o: Mobile Technology does not have an influence on customer loyalty of customers of clothing retailers.

- H21: Mobile Technology does have an influence on customer loyalty of customers of clothing retailers.

The relationship between the independent variable and the intervening variable

- H3o: Customer satisfaction does have a significant influence on customer loyalty of customers of clothing retailers. 
- H31: Customer satisfaction does have a significant influence on customer loyalty of customers of clothing retailers.

The role of the mediator variable in the relationship between the independent variable and the dependent variable.

- H3o: Mobile technology does not play a mediating role in the linkage between customer satisfaction and customer loyalty among customers of clothing retailers.

- $\quad H 3_{1}$ : Mobile technology does play a mediating role in the linkage between customer satisfaction and customer loyalty among customers of clothing retailers.

\section{Literature Review}

\subsection{Customer satisfaction}

According to Kotler and Armstrong (2006:8), customer satisfaction is the extent to which products perceived performance matches buyer's expectations of those products. The ultimate goal of any firm is to ensure that the customer that purchases its product or service is satisfied (Brink \& Berndt, 2004:49). Customers have different expectations of a firm's product or service offerings. Hence, positive customer perceived value accrues when the customers' experiences of products or services offered by firms are equal or exceed their expectations of the product or service.

Furthermore, customer satisfaction is renowned as the foundation for the building and maintenance of long-term customer relationships and loyalty. Customer satisfaction is important because research indicates that customers' intentions to repurchase a product or service are determined primarily by satisfaction with prior use (Anderson \& Fornell, 2000:870).

Customer satisfaction is important to firms. This is because meeting and exceeding customers' expectations results in many benefits to firms. In addition, customer satisfaction is characterised by positive word of mouth publicity and customer retention (Bateson \& Hoffman, 2011:295). Customer satisfaction is associated with positive word of mouth. According to Ranaweera and Prabhu (2003:376) customers are willing to inform others of service incidents that give them satisfaction. Therefore, meeting and exceeding customer expectations may result in customers informing others of the service experience. Customer satisfaction is associated with recommendations and repeat intentions Kassim and Abdullah (2010:844).

According to Bateson and Hoffman (2011:297) satisfied customers often purchase more frequently and are less likely to be lost to competitors than are dissatisfied customers. This is because satisfied customers will probably return to the firm and make additional purchases. Firms with high customer ratings are also able to protect themselves from competitive pressure especially price competition. According to Kotler and Keller (2012:21) customer satisfaction results in loyal customers and they do not switch to competitors. Customer satisfaction also leads to customer loyalty which results in better business performance (Kotler \& Keller 2012:27). The following section focuses on the antecedents of Customer satisfaction.

\subsection{Customer Loyalty}

Building and maintaining customer loyalty, has been a central theory and practice in achieving sustainable competitive advantage (Gommans, Krishan \& Scheddold, 2001:43). . According to Brink and Berndt (2004:32) customer loyalty implies that customers are committed to purchasing products and services from a specific firm and will resist the activities of rival firms attempting to attract their patronage.

As markets became more competitive many firms realised the importance of retaining current customers and some have initiated a variety of activities to improve customer loyalty (Mc Mullan \& Gilmore 2007:1084). In the current global marketplace, competition has intensified (Sivadas and Baker-Prewitt 2000:74). Therefore, customer loyalty has become a strategic objective for most firms because it is a source of wealth, achieved through attracting and building long-term relationships with customers. Singh and Sirdeshmukh (2000:15) purport that customer loyalty is rapidly becoming the market place currency of the twenty first century.

According to Pfeifer (2005:79), it costs five times more to acquire new customers than to retain an existing one. Therefore, it is a common viewpoint that it makes commercial sense for firms to retain current customers before acquiring new ones (Walsh, Groth \& Wiedman, 2005:421). Customer acquisition does not ensure long-term success of a firm, hence, most firms realise that customer acquisition must be balanced through the building of customer loyalty. Over a period of years, a school of thought has emerged regarding customer loyalty that embraces this principle that it costs more to acquire a new customer than it is to retain an existing one (Duffy, 2005:284). This perception has become 
prevalent among marketers and became one of the standard concepts in customer-loyalty building.

Loyal customers have higher retention rates, commit a higher share of their spending and are more likely to recommend others to become customers of the firm (Zeithaml, 2000:70). Therefore, this has resulted in firms shifting focus to customer loyalty and the building of long-term relationships with customers. However, Brink and Berndt (2004:32) argue that customer loyalty is about extending beyond having customers make repeat purchases and being content with their experiences and products or services they bought, it is more specifically focused on ensuring that a customer develops commitment to a certain market offering (Brink \& Berndt 2004:32).

\subsection{The Link between Customer Satisfaction and Customer Loyalty}

In times of severe competition and rising customer expectations, firms are highly interested in keeping existing customers (Homburg \& Giering 2001:43). Hence, a strong concentration on customer satisfaction as an antecedent of customer loyalty has developed. In addition, it is believed that customer loyalty contributes to higher shareholder value and asset efficiency. Therefore, achieving high levels of customer satisfaction and loyalty have become essential business objectives. Typically, customer satisfaction is regarded as an immediate antecedent to customer loyalty (Anderson \& Sullivan 1993:125).

Several publications provide empirical evidence of a positive relationship between customer satisfaction and customer loyalty. There is a positive association between customer satisfaction and customer loyalty (Rowley, 2000). Homburg and Giering (2001) argue that there is a strong positive relationship between customer satisfaction and customer loyalty. Customer loyalty can be considered a by-product of customer satisfaction (Gable, Fiorito \& Topol 2008:38); however, there is an absence of an obvious simple association between customer satisfaction and customer loyalty. According to Oliver as cited by Wallace et al., (2004:252) satisfaction is the "seed" out of which loyalty develops enhancing satisfaction is an important means for achieving loyalty. In addition, for a customer to have true customer loyalty there should be total satisfaction.

Loyalty does not develop overnight but is rather a stream of experiences, built on a customer's experience over a long period of time. In addition, Gee, Coates and Nicholson, (2008:365) suggests that multiple experience with products and services should be satisfactory to lead to the positive predisposition of long term loyalty. However, even satisfied customers switch to other firms, if they believe that they will receive better services from a rival firm. Homburg and Giering (2001:45) argue that a single transaction producing a state of satisfaction is unlikely to lead to long term loyalty. Therefore, a single transaction that leads to dissatisfaction is also unlikely to result in customers switching to competitors. Moreover, dissatisfied customers may also stay with a firm and spread negative word-of-mouth. Research has shown that when consumers are completely satisfied, they are less likely to defect or switch to competitors.

This suggests that the intensity of satisfaction influences the extent of customer loyalty (Rowley, 2000). Rowley (2005:369) suggests that customer satisfaction can be a differentiating element of a firm's service offer. The author further purports that overall satisfied customers tend to become loyal customers. Therefore, since different factors seem to influence the propensity to be loyal under conditions of low and high satisfaction, it could be assumed that the form of the relationship between customer satisfaction and loyalty is altered at different levels of satisfaction. As a result, it is not simple to turn loyalty into profits (Keiningham, Cooil, Andreassen \& Aksoy 2007; Vázquez-Casielles, 2009). Despite the lack of consensus, however, researchers and empirical evidence suggest that there exists some relationship between customer satisfaction and customer loyalty.

\subsection{Mobile Technology}

The explosive development and worldwide diffusion of communication practices involving mobile media technologies are naturally attracting the interest of scholars (Craig, 2007:386). According to Siau, Lim and Shen (2001:7), firms are now adopting new types of e-commerce transactions conducted through mobile devices (for example cell phones) using wireless telecommunication networks and other wired e-commerce technologies that are termed mobile commerce ( $\mathrm{m}$ commerce). The clothing retail industry is a very competitive industry; hence, the adoption of mobile technology as a communication strategy is highly essential. Mobile marketing has become increasingly important in retailing due to the virtues of the mobile medium that makes it both time sensitive and location sensitive (Shankar, Venkatesh, Hofacker \& Naik 2010:3). In addition, Muller-Veerse (2000) states that mobile marketing is characterised by personalisation, localisation, ubiquity, and convenience. Therefore, mobile marketing has the potential to change the paradigm of retailing (Shankar, et al., 2010:3).

Advancement in wireless technology and mobile devices has resulted in a new kind of e-commerce termed mobile 
commerce. New types of e-commerce transactions, conducted through mobile devices using wireless telecommunication networks and other wired e-commerce technologies, are termed mobile commerce (m-commerce) (Siau, et al., 2001). Mobile commerce transactions are conducted via mobile devices using wireless telecommunication networks and other wired e-commerce technologies. Mobile commerce extends contemporary internet sales channels into more instantaneous and personalised mobile environments.

The mobile phone has arguably evolved into the first truly personal computer due to the fact that it combines communication and computing capabilities with mobility and personality (Sirkka \& Lang 2005:7). As opposed to desktop or laptop computers, the mobile phone is typically never separated from, but always with its user (Sirkka \& Lang 2005:7). Therefore, users tend to develop close partnerships with their mobile devices (Kopomaa 2000, Rheingold 2002).

The clothing retailing industry has a mixture of formal and informal traders and that is an element that sets them apart. Mobile technology plays a mediating role in communicating what these clothing retailers have to offer. It also helps in fostering relationships for the purpose of building customer loyalty among the customers. The extremely competitive nature of the clothing retail industry necessitates a marketing investigation to identify how mobile technology plays a mediating role between customer satisfaction and customer loyalty.

\section{Methodology}

The research was conducted in Eastern Cape Province of South Africa. The Province has ample retail clothing outlets to cater for the diverse needs of the cosmopolitan inhabitants. Customers for retail outlets in this province where targeted thus, the population for this study constitute retail outlets customers. This research was survey-based and applied a quantitative approach for acquiring numeric data. A questionnaire containing mainly structured questions was used as a data collection instrument. In addition, the researcher used secondary data from existing literature for the study. The sample size was 180 respondents' that were deemed appropriate for this research. The study applied a non-probability sampling method. This method was used because it is least time consuming and least expensive compared to other sampling techniques (Cant, Gerber-Nel, Nel \& Kotze 2005:96). The convenience sampling method was applied in selecting the sample elements because it accommodates the lack of co-operation often experienced in mall surveys. Convenient sampling selects elements in an unstructured manner from the population and is employed in many practical situations (Tustin, Martins, Ligthelm \& Van Wyk, 2005:346).

The survey was a mall-intercept; therefore the respondents' were intercepted in the shopping malls where the three outlets conduct their business. The researcher conveniently selected customers of the three clothing retailers willing to participate in the survey. The elements were intercepted in malls and the central business area for the three clothing retailers. Data collected was analysed using the Statistical Package for Social Sciences (SPSS) statistical software. Multiple regression analysis was used to analyse data inferentially.

\subsection{Hypotheses Testing}

The hypotheses were tested using multiple regression analysis. For this analysis the mediator variable was mobile technology, the independent variable was customer satisfaction and the dependent variable was customer loyalty. A mediator variable in statistics is a variable that describes how, rather than when, effects will occur by accounting for the relationship between the independent and dependent variable (Mac Kinnon, 2008:78). The mediating relationship is one in which the path relating the independent variable to the dependent variable is mediated by an intervening variable. However, moderating variables pinpoint the conditions under which an independent variable exerts its effects on a dependent variable (Mac Kinnon, 2008:78).

\section{Findings}

The results from reliability analysis are presented first and multiple regression analysis results for the hypotheses formulated for this study are presented thereafter.

\subsection{Reliability}

Cronchbach's alpha test was performed on each construct to measure internal consistency for the overall measures. The recommended cut-off score for a reliable measurement scale is 0.60 ; otherwise, it indicates unsatisfactory internal consistency reliability (Malhotra 2004:268). The Cronchbach alpha co-efficient for all items is 0.974 which is above 0.6, 
which means the measurement instrument was reliable. Cronchbach alpha coefficient results for individual construct used for this research are presented in Table 1.

Table 1: Cronchbach Alpha of Constructs

\begin{tabular}{|l|c|}
\hline Variable & Cronchbach Alpha Co-efficients \\
\hline Perceptions on Mobile Technology & 0.925 \\
\hline Information on Mobile technology & 0.977 \\
\hline Customer Satisfaction & 0.874 \\
\hline Customer Loyalty & 0.892 \\
\hline
\end{tabular}

The empirical results on Table 1 show that Cronchbach alpha co-efficients of the individual questionnaire items are all above 0.60 which is the benchmark for reliability. Hence, it can be concluded that the questionnaire items were reliable. Although a 0.6, co-efficient was used as benchmark in this study; lower thresholds are sometimes used in literature.

\subsection{Multiple Regression Analyses}

The testing of hypotheses was conducted in four stages to test for the mediating role. Baron and Kenny (1986) proposed a four-step approach to test for mediation in which several regressions are conducted and the significance of co-efficient is examined at each stage:

- Step 1: Conduct a simple regression analysis with X predicting $Y$,

- Step 2: Conduct a simple regression analysis with $X$ predicting $M$,

- Step 3: Conduct a simple regression analysis with $M$ predicting $Y$ and

- Step 4: Conduct a multiple regression analysis with $X$ and $M$ predicting $Y$.

Four regression analyses were conducted and the significance of the co-efficient was examined at each stage. The following primary hypothesis was tested applying this four-step approach. The first step was to establish the relationship between customer satisfaction and customer loyalty.

Table 2: Regression results of Customer Satisfaction on Customer Loyalty

\begin{tabular}{|c|c|c|c|c|}
\hline Variable & R Squared & Significance & Beta Co-efficient & t-statistic \\
\hline Customer Satisfaction & 0.752 & 0.000 & 0.836 & 23.188 \\
\hline
\end{tabular}

The findings on Table 2 show that the model is significant because the R square value is close to 1 . Gujarati and Porter (2010:74) purport that if the $\mathrm{R}$ square value is close to 1 it means that the model is fit. Therefore, the model is significant because the $\mathrm{R}$ square value is 0.752 . This indicates that the predictor variable which is customer loyalty in the multiple regression analysis is explained by 75.2 percent of the variance in the dependent variable which is customer satisfaction. Therefore, 75.2 percent of the possible change in customer loyalty is caused by customer satisfaction. The beta coefficient reflects a contribution of 0.836 of customer satisfaction to customer loyalty. This indicates that one unit increase in customer satisfaction will increase customer loyalty by 83.6 percent when considering beta. The T-statistic of 23.188 is greater than 2 and is significant since 2 is the benchmark used in this study. The p-value of 0.000 is less than 0.05 hence the findings show that there is a significant relationship between customer satisfaction and loyalty. Hence, the null hypothesis (H10: Customer Satisfaction does not have an influence on customer loyalty of customers of clothing retailers) is rejected and the alternative hypothesis accepted.

The second step was to establish the relationship between customer satisfaction and the intervening variable (mobile technology). The empirical findings on Table 3 show that the model is significant because the $\mathrm{R}$ square value of 0.532 is close to 1 and therefore significant. This indicates that 53.2 percent of the variance in the mediator variable which is mobile technology is explained by the independent variable which is customer satisfaction. Therefore, 53.2 percent of the possible change in Mobile technology is caused by customer satisfaction. The T-statistic of 14.194 is greater than 2 and thus, significant. The beta co-efficient reflects a contribution of 1.001 on the mediating variable.

Table 3: Regression of Customer Satisfaction on the Intervening Variable

\begin{tabular}{|c|c|c|c|c|}
\hline Variable & R Squared & Significance & Beta Co-efficient & t-statistic \\
\hline Customer Satisfaction & 0.532 & 0.000 & 1.001 & 14.194 \\
\hline
\end{tabular}


This indicates that one unit increase in customer satisfaction will increase customer satisfaction by 1 percent when considering beta. The $p$-value of 0.000 is less than 0.05 hence the findings show that there is a significant relationship between customer satisfaction and the intervening variable, mobile technology. Thus the null hypothesis (H20: Mobile Technology does not have an influence on customer loyalty of customers of clothing retailers) was rejected.

The third step was to establish the relationship between intervening variable (mobile technology and customer loyalty. The findings on Table 4 show that the model has an $\mathrm{R}$ square value of 0.348 . This indicates that the intervening variable which is mobile technology is explained 34.8 percent of the variance in the dependent variable which is customer loyalty.

Table 4: Regression of Mobile Technology on Customer Loyalty

\begin{tabular}{|c|c|c|c|c|}
\hline Variable & R Squared & Significance & Beta Co-efficient & t-statistic \\
\hline Mobile Technology & 0.348 & 0.000 & 0.415 & 9.726 \\
\hline
\end{tabular}

This indicates that 34.8 percent of the variance in customer loyalty is attributed to mobile technology. The t-statistic of 9.726 is greater than 2 hence; showing significance. The beta co-efficient reflects a contribution of 0.415 of the intervening variable on the independent variable. This indicates that one unit increase in mobile technology usage increases customer loyalty by 41.5 percent considering beta. The $p$-value of 0.000 is less than 0.05 hence the findings show that there is significant relationship between the intervening variable and customer loyalty. The null hypothesis (H3o: Customer satisfaction does have a significant influence on customer loyalty of customers of clothing retailers) was rejected and the alternative accepted.

The last step was to establish the relationship between customer satisfaction and mobile technology on customer loyalty. The findings on Table 5 show that the model is significant because the R square value of 0.756 is close to 1 and significant. This $\mathrm{R}$ square value is the predictive accuracy and it reflects the percentage of variance in the dependent variable explained by the independent variable (Allua \& Thompson 2009:170). An R square value of approximately 0.756 reflects that $75.6 \%$ of the variance emanates from the predictor variables. This indicates that 75.6 percent of the possible change in customer loyalty is caused by mobile technology and customer satisfaction. The beta co-efficient of customer satisfaction contributes 0.900 to the dependent variable while mobile technology with a beta-co-efficient of 0.064 , also contributes to customer loyalty.

Table 5: Regression of Customer Satisfaction and Mobile Technology on Customer Loyalty

\begin{tabular}{|c|c|c|c|c|}
\hline Variables & R Squared & Significance & Beta Co-efficient & t-statistic \\
\hline Customer Satisfaction & 0.756 & 0.000 & 0.900 & 17.162 \\
\hline Mobile technology & 0.756 & 0.005 & 0.064 & 1.676 \\
\hline
\end{tabular}

This indicates that one unit increase in customer satisfaction will increase customer loyalty by 0.9 percent. This indicates that one percent increase in mobile technology will increase customer loyalty by 0.06 percent. The p-values of both variables are less than 0.05 hence; the findings show that there is a significant relationship mobile technology and customer loyalty and also between customer satisfaction and customer loyalty. Thus, mobile technology does play a mediating role in the linkage between customer satisfaction and customer loyalty among customers of clothing retailers so the null hypothesis was rejected.

\subsubsection{Interpretation of the hypothesis result}

According to Mackinnon, Fairchild and Fritz (2007), the purpose of step 1 to 3 is to test that zero-order relationships among the variables exist. Researchers conclude that if one or more of these relationships are non-significant, mediation is not possible or likely. In this case steps 1 to 3 are significant, hence, mediation exists. The null hypothesis is therefore, rejected and the alternative hypothesis accepted, because the findings are significant in all the steps. However, the findings show that mobile technology only partially mediates the linkage between customer satisfaction and customer loyalty. The p-values of both customer satisfaction and mobile technology are significant and are less than 0.05 hence there is partial mediation. According to Mackinnon et.al. (2007), in the 4-step model, partial mediation is supported if both the independent variable and the mediator variable significantly predict the dependent variable. Therefore, the null hypothesis is rejected and the alternative hypothesis is accepted. 


\section{Managerial Implications}

Clothing retailers should develop and implement customer relationship management strategies that incorporate mobile technology mediums such as mobile phones. Clothing retailers should also utilise this mobile customer relationship management strategy to build long-term B2C relationships through the application of mobile phones. Marketing managers should ensure that messages sent to customers create positive perceptions among customers. As customers become more educated and technologically empowered, they have more choices of communicating with firms. Therefore, mobile technology is a major opportunity for clothing retailers to enhance customer satisfaction, to augment customer loyalty and to increase customer retention though the implementation of SMSs and MMSs between customers' mobile phones and the marketing information systems of the clothing retailers

Mobile marketing to current and prospective customers could also be used as a mobile technology strategy by clothing retailers; this is because mobile phones are time and location flexible that ensure easy contact with a customer. Clothing retailers could further develop a feedback system whereby customers can rate service-experiences via SMS or via mobisites or for conducting short customer surveys. Customers, on the other hand can lodge complaints about a service-experience through this medium.

Clothing retailers should be reminded that mobile technology brings the possibility of new transactions and relationship building but it also has some challenges. Clothing retailers should have access to the necessary technology infrastructure that shares certain information and sends and receives information instantly. Mobile technology could assist clothing retailers in developing successful marketing strategies by promoting an understanding of customer needs and by improving the service-process through feedback from satisfied customers. Customer satisfaction is also promoted through mobile technology, firstly, by building customer expectations through the mobile medium and, secondly, meeting or exceeding these expectations. However, clothing retailers may have to target specific customers through mobile technology in order to build profitable relationships.

In the light of intense competition in the clothing retail market, only satisfying customers may be insufficient, therefore, clothing retailers have to focus relentlessly on improving customer satisfaction as well as on improving customer perceptions about service quality. Marketing managers should set quality standards that guarantee the quality of services and continuously monitor and improve the service-processes to guarantee service quality and excellent service-experiences. Employees should be subjected to creative internal marketing practices as well as on-going training by the firm.

Finally, to maintain long-term customer relationships, clothing retailers should engage in loyalty programmes from which customers derive economic and social benefits. Customer loyalty could be enhanced through the use of mobile technology. A mobile newsletter, accessible via mobile phones, sharing important news about the clothing retailer, could be launched as part of this loyalty drive. Mobile communication strategies could also be adapted to allow for customer need differentiation and for strengthening particular relationships and loyalty over time. Overall, the focus of the mobile communication strategies should be to emphasise a striking mobisite design and SMS interface to provide visually appealing messages using attractive colours.

\section{Conclusion}

The research focused on one town in the Eastern Cape Province; however the research may be applicable to other clothing retailers in South Africa and other African countries. The research managed to find out the mediating role mobile technology can play in the link between customer satisfaction and customer loyalty. Therefore, any strategies the firms implement that use mobile technology should be made to enhance customer satisfaction and customer loyalty. Mobile communication strategies that address customer need differentiation and that strengthen particular relationships and loyalty over time should be adapted.

\section{References}

Abbassi, A.S. Khalid, W., Azam, M. \& Riaz, A. (2010). Determinants of Customer Satisfaction in Hotel Industry in Pakistan. European Journal of Scientific Research, 48(1): 97-108.

Allua, S. \& Thompson, C.B. (2009). Inferential Statistics and Hypothesis Testing. Air Medical Journal, 28(4): 168-171.

Anderson, E.W. \& Fornell, C. (2000). Foundations of the American Customer Satisfaction Index. Total Quality Management, 11 (7): $869-$ 882.

Anderson, E.W. \& Sullivan, M.W. (1993). The Antecedents and Consequence of Customer Satisfaction for Firms. Marketing Science, 12 
(2): 125-143.

Baron, R.M. \& Kenney, D.A. (1986). The Moderator Mediator Variable Distinction in Social Psychological Research: Conceptual, Strategic and Statistical Considerations. Journal of Personality and Social Psychology, 51 (6): 1173-1182.

Bateson, J.E.G. \& Hoffman, K.D. (2011). Services Marketing. Van Couver: South Western.

Brink, A. \& Berndt, A. 2004. Customer Relationship Management and Customer Service. 120-132 Lansdowne: Juta and Co. Ltd.

Cant, M., Gerber-Nel, C., Nel, D. \& Kotze, T. (2005). Marketing Research. Claremont: New Africa Books Pty Ltd.

Duffy, D.L. (2005). The Evolution of the Customer Loyalty Strategy. Journal of Consumer Marketing, 22 (5): 284-285.

Evanschitzky, H. and Wunderlich, M. (2006). An Examination of Moderator Effects in the Four-Stage Loyalty Model. Journal of Service Research, 8 (4): 330-345.

Fashion Apparel Industry Overview (2011). [On-line]. Available: http://www.fashionproducts.com/fashion-apparel-overview.html [Accessed: 1 September 2011]. Homburg, C. \& Giering, A. (2001). Personal Characteristics as Moderators of the Relationship between Customer Satisfaction and Loyalty- An Empirical Analysis. Psychology and Marketing, 18 (1): 43-66.

Gable, M., Fiorito, S. and Topol, M. (2008). An Empirical Analysis of the Components of Retailer Customer Loyalty Programs. International Journal of Retail and Distribution Management, 36 (2): 32-49.

Gee, R., Coates, G. and Nicholson, M. (2008). Understanding and Profitably Managing Customer Loyalty. Marketing Intelligence and Planning, 26 (4): 359-374.

Gommans, M., Krishan, K.S. \& Scheddold, K.B. (2001). From Brand Loyalty to E-Loyalty: A Conceptual Framework. Journal of Economic and Social Research, 3 (1): 43-58.

Gujarati, D. \& Porter, D. (2010). Essentials of Econometrics. New York: Mc Graw Hill.

Kassim, N. \& Abdullah, N.A. (2010). The Effect of Perceived Service Quality Dimension On Customer Satisfaction, Trust And Loyalty In e-Commerce Settings. Total Quality Management and Business Excellence. 19 (7): 843-853.

Keinigham, T.L., Cooil, B., Andreassen, T.W. \& Aksoy, L. (2007). A Longitudinal Examination of 'Net Promoter' of Firm Revenue Growth. Journal of Marketing, 7(3): 39-51.

Kopomaa, T. (2000). City in your Pocket. The Birth of Mobile Society. Helisinki: Gaudeamus.

Kotler, P \& Armstrong, G. (2012). Principles of Marketing - Global and South African Perspectives. 200-220, Cape Town: Pearson Education South Africa.

Mac Kinnon, D.P. (2008). Introduction to Statistical Mediation Analysis. New York: Erlbaum.

Mac Kinnon, D.P., Fairchild, A.J.\& Fritz, M.S. (2007). Mediation Analysis. Annual Review of Psychology, 58: 593-614.

Malhotra, N.K. (2004). Marketing Research - An Applied Orientation. Upper Saddle River: Pearson Prentice Hall.

Mc Mullan, R. \& Gilmore, A. (2007). Customer Loyalty an Empirical Study. European Journal of Marketing, 42 (9/10): $1084-1094$.

Muller-Veerse, F. (2000). Mobile Commerce Report. Durlacer Research. [On-line]. Available:www.durlacer.com [Accessed: 9 March 2011].

Pfeifer, P. (2005). The Optimal Ratio of Acquisition and Retention Costs. Journal Of Targeting, Measurement and Analysis for Marketing, 13 (2): 179-188.

Ranaweera, C. \& Prabhu, J. (2003). The Influence of Satisfaction, Trust and Switching Barriers on Customer Retention in Continuous Purchase Setting. International Journal of Service Industry Management, 14(4): 374-395.

Rheingold, H. (2002). Smart Mobs: The Next Social Revolution. Cambridge: Perseus Publishing.

Roberts-Lombard, M. (2009). Customer Retention Strategies Implemented by Fast-Food Outlets in the Gauteng, Western Cape and Kwazulu Natal Provinces in South Africa-A Focus on Something Fishy, Nandos and Steers. Journal of marketing Management, 1(2): 070-080.

Rowley, J. (2000). Loyalty Kiosks: Making Loyalty Cards Work. British Food Journal, 102 (5/6): 390-397.

Rowley, J. (2007). Reconceptualising the Strategic Role of Loyalty Schemes. Journal of Consumer Marketing, 24 (6): 366-374.

Shankar, V., Venkatesh, A., Hofacker, C. \& Naik, D. (2010). Mobile Marketing in the Retail Enviroment: Current Insights and Future Research Avenues. The Journal of Interactive Marketing, 24 (2): 111-120.

Singh, J. \& Sirdeshmukh, D. (2000). Agency and Trust Mechanisms in Relational Exchanges. Journal of Marketing, 66 (1): $138-159$.

Sirkka, L.J. \& Lang K.R. (2005). Managing the Paradoxes of Mobile Technology. Information Systems Management, 22 (4): 7-23.

Siau, K., Lim, E.P. \& Shen, Z. (2001). Mobile Commerce: Promises, Challenges and Research Agenda. Journal of Database Management, 12 (3): 4-13.

Sivadas, E. and Baker-Prewitt, J. (2000). An Examination of the Relationship between Service Quality, Customer Satisfaction and Store Loyalty. International Journal of Retail and Distribution Management, 28 (2): 73-82.

Tustin, D.H., Martins, J.H., Ligthelm, A.A. \& Van Wyk, H. (2005). Marketing Research in Practice. Pretoria: Unisa Press

Vasquez-Casielles, R. (2009). Customer Satisfaction and Switching Barriers Effects on Repurchase Intentions, Positive Recommendations and Price Tolerance. Journal of Applied Social Psychology, 39 (10): 326-356.

Wallace, D., Giese, J. \& Johnson, J. (2004). Customer Retailer Loyalty in the Context of Multiple Channel Strategies. Journal of Retailing, 80: 249-263.

Zeithaml, V.A. (2000). Service Quality, Profitability, and the Economic Worth of Customers: What We Know and What We Need to Learn. Journal of the Academy of Marketing Science, 28: 67-85.

Zeithaml, V.A., Rust, R.T. and Lemon, K.N. (2001). The Customer Pyramid: Creating and Serving Profitable Customers. California Management Review, 43 (4): 118-142. 